\title{
A Graft-Based Chemotherapy Method for Screening Effective Molecules and Rescuing Huanglongbing-Affected Citrus Plants
}

\author{
Muqing Zhang, Charles A. Powell, Ying Guo, Melissa S. Doud, and Yongping Duan
}

First author: IFAS-IRREC, University of Florida, Fort Pierce 34945, and Fujian Agricultural and Forestry University, Fuzhou, 350002, China; second and third authors: IFAS-IRREC, University of Florida, Fort Pierce 34945; and fourth and fifth authors: Department of Agriculture-Agricultural Research Service, USHRL, Fort Pierce, FL 34945.

Accepted for publication 29 February 2012.

\begin{abstract}
Zhang, M., Powell, C. A., Guo, Y., Doud, M. S., and Duan, Y. 2012. A graft-based chemotherapy method for screening effective molecules and rescuing huanglongbing-affected citrus plants. Phytopathology 102:567574.

Huanglongbing (HLB) is the most devastating disease of citrus. The global citrus industry is in urgent need of effective chemical treatments for HLB control because of its rapid spreading worldwide. Due to the fastidious nature of the pathogens, and the poor permissibility of citrus leaf surfaces, effective screening of chemicals for the HLB control can be challenging. In this study, we developed a graft-based chemotherapy method to rapidly screen potential HLB-controlling chemical compounds.

affected scion-rootstock combination, and demonstrated the HLB bacterial titer was the critical factor in transmission. The HLB-affected lemon scions had a high titer of HLB bacterium, survival rate $(83.3 \%)$, and pathogen transmission rate $(59.9 \%)$. Trifoliate, a widely used commercial rootstock, had the highest survival rate $(>70.0 \%)$ compared with grapefruit $(52.6 \%)$ and sour orange $(50.4 \%)$. Using this method, we confirmed a mixture of penicillin and streptomycin was the most effective compounds in eliminating the HLB bacterium from the HLB-affected scions, and in successfully rescuing severely HLB-affected citrus germplasms. These findings are useful not only for chemical treatments but also for graft-based transmission studies in HLB and other Liberibacter diseases.
\end{abstract} In addition, we improved transmission efficiency by using the best HLB-
Citrus is one of the most important fruit crops in the world. Various biotic stresses, such as citrus huanglongbing (HLB) are major problems that hinder the industry worldwide $(19,20)$. HLB, also known as greening, is one of the most destructive diseases of citrus (6). HLB is associated with three species of fastidious and phloem-limited $\alpha$-proteobacteria in the genus 'Candidatus Liberibacter': ' $C a$. Liberibacter asiaticus' (Las), ' $C a$. Liberibacter africanus' (Laf), and 'Ca. Liberibacter americanus' (Lam) (7,19, $22,44)$. No commercial citrus cultivars are resistant to HLB, but disease severity may vary with citrus genotypes $(15,30,33,41)$. In general, yellow shoots and blotchy mottle on the leaves are characteristics of HLB symptoms; for yellow shoots, vein yellowing often begins on leaves, followed by yellowing or mottling of an entire leaf, along with vein corking in certain citrus cultivars. Premature defoliation and twig dieback are often displayed in the late stage of the disease. As the disease severity increases, the yield and quality of citrus fruit are drastically reduced (2).

HLB is a systemic disease transmitted by insect (Diaphorina citri or Trioza erytreae) and grafting with a prolonged latency period $(21,27)$. The bacterial pathogens reside in the phloem of citrus and are often unevenly distributed in the infected plants $(12,22)$. Due to the lack of resistant cultivars to HLB and the rapid spreading of the disease, it is very difficult to control this disease in many parts of the world, especially in the newly infected areas, such as Florida, USA and Sao Paulo, Brazil $(19,20)$. There is an urgent need for effective chemicals to control HLB as a short-term solution to save the Florida citrus industry.

Corresponding author: Y. Duan; E-mail address: Yongping.duan@ ars.usda.gov

*The $\boldsymbol{e}$-Xtra logo stands for "electronic extra" and indicates that Figure 1 appears in color online.

http://dx.doi.org/10.1094/PHYTO-09-11-0265

(c) 2012 The American Phytopathological Society
Due to the fastidious nature of the pathogens, all inoculations and transmissions require the use of infected plants as sources of inoculums though the bacterium can be transmitted to citrus plants via insect vector $(21,27)$, dodder (Cuscuta pentagona) $(16,17)$, and/or grafting $(12,24)$. Because of the relatively high efficiency of pathogen transmission, the graft-based method is preferred for investigating citrus response to Las bacterial infection $(12,24)$. However, there have been no reports of using a graftbased method for screening antimicrobial compounds against HLB bacteria. Because the epicuticular wax on the surface of citrus leaves is an obstacle to foliar uptake of compounds into the phloem $(8,9)$, uptake through soaking is more effective (46).

In a previous report, a regeneration-based test system using Las-infected periwinkle (Catharanthus roseus) cuttings was developed to screen effective molecules for the control of citrus HLB while assessing their phytotoxicity (46). Using this model plant, penicillin $G$, separately and in combination with streptomycin was identified as an effective HLB chemotherapy compound $(46,47)$. In this article, we describe simple but effective graft-based chemotherapy method with best selection of HLBaffected citrus scion and rootstock for rapidly screening and evaluating potential chemical compounds, as well as for rescuing HLB-affected citrus germplasm and breeding materials.

\section{MATERIALS AND METHODS}

Graft transmission of Las bacterium using different scions and rootstocks. The side grafting method was chosen to ensure a high titer and a high transmission rate of Las bacterium. HLBaffected twigs of $\approx 10 \mathrm{~cm}$ long were collected from infected trees with typical HLB symptoms (blotchy mottle and yellow shoots), which were confirmed by quantitative PCR (qPCR) as described previously $(23,47)$. Twigs were kept in transparent plastic bags and placed in a cooler with ice to maintain their freshness. All 
TABLE 1. Transmission efficiency (rootstock infection rate) of 'Candidatus Liberibacter asiaticus' and scion survival rate of different citrus species with distinct huanglongbing (HLB) symptoms used as scions or rootstocks at 6 months after inoculation

\begin{tabular}{llc}
\hline Treatments & $\begin{array}{c}\text { Scion survival } \\
\text { rate }(\%)\end{array}$ & $\begin{array}{c}\text { Rootstock infection } \\
\text { rate }(\%)^{\mathrm{z}}\end{array}$ \\
\hline $\begin{array}{l}\text { HLB symptoms } \\
\text { Yellow shoot }\end{array}$ & $54.15 \pm 29.49 \mathrm{a}$ & $25.13 \pm 23.17 \mathrm{a}$ \\
$\quad$ Blotchy mottle & $62.67 \pm 20.36 \mathrm{a}$ & $48.38 \pm 27.10 \mathrm{a}$ \\
Scions & $62.95 \pm 18.33 \mathrm{a}$ & $58.92 \pm 29.88 \mathrm{a}$ \\
$\quad$ Lemon & $54.52 \pm 18.32 \mathrm{a}$ & $20.93 \pm 12.92 \mathrm{~b}$ \\
Pummelo & $52.55 \pm 9.66 \mathrm{a}$ & $25.95 \pm 32.22 \mathrm{a}$ \\
Rootstocks & $50.43 \pm 25.22 \mathrm{a}$ & $44.20 \pm 45.81 \mathrm{a}$ \\
$\quad$ Grapefruit & $73.23 \pm 6.18 \mathrm{a}$ & $40.13 \pm 18.65 \mathrm{a}$ \\
$\quad$ Sour orange &
\end{tabular}

${ }^{\mathrm{z}}$ Least square means are derived from the three-way interactions of HLB symptoms, scions, and rootstocks. Means followed by the same letter are not significantly different from each other within the same treatment (HLB symptoms, scions, and rootstocks, respectively) at 95\% level $(P \leq 0.05)$ according to the LINES option of the LSMEANS statement in SAS procedure GLIMMIX. experimental plants were grown in an insect-proof greenhouse. A split-plot design was used to evaluate citrus responses to Las bacterial infection. HLB symptoms of blotchy mottle and yellow shoots were the whole plot factor, while rootstocks (grapefruit, sour orange, and trifoliate) and HLB-affected scions (lemon and pummelo) were considered as the subplot treatments. Inocula, consisting of two 3- to 4-cm-long budsticks from different cultivars (lemon and pummelo) showing different HLB symptoms (yellow shoot and blotchy mottle), were grafted separately onto 15 plants each of grapefruit ('Duncan'), sour orange, and trifoliate orange ('Swingle') (Table 1). Each budstick was covered by plastic tape for 3 weeks. First samples for DNA extraction were taken 4 months after inoculation; subsequent samplings were taken at 2 months intervals. The scion survival rates were defined as the number of scions that survived out of the total number of grafted scions. Transmission efficiency was determined as the infection percentage of the grafted plants, which tested Las positive by real-time qPCR with threshold cycle $(\mathrm{Ct})$ values less than 32.0. The bacterial titers were quantified by qPCR

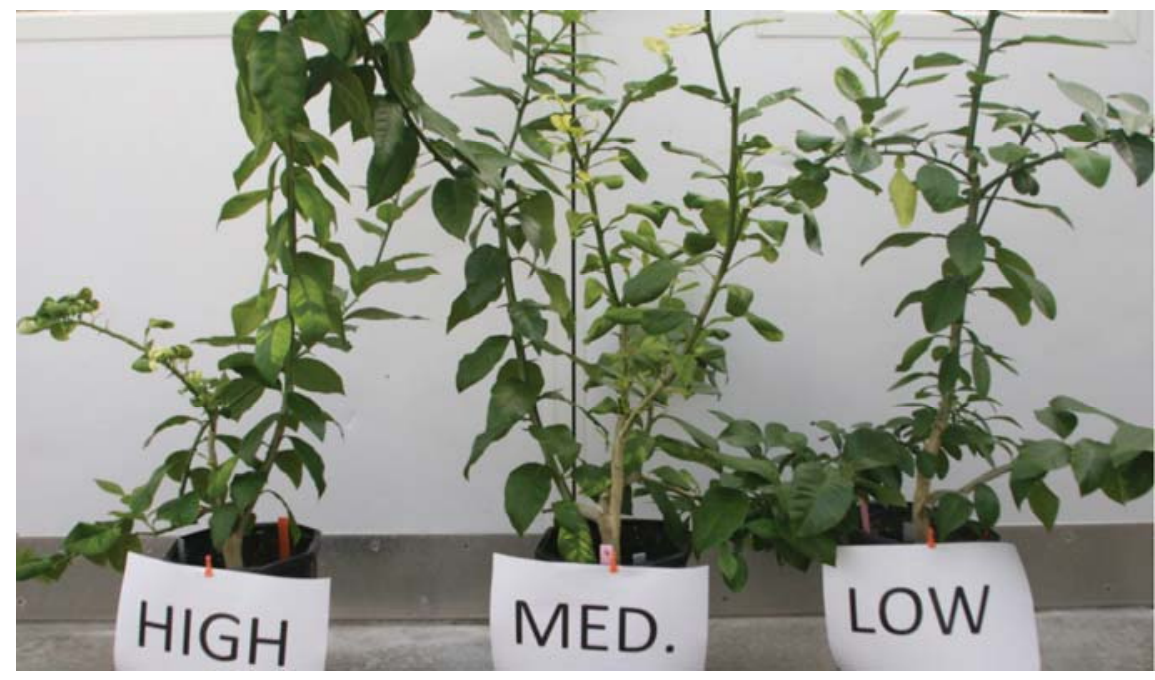

Fig. 1. Huanglongbing (HLB)-affected grapefruit ('Duncan') plants with graft-inoculation of infected lemon scions containing different titers of 'Candidatus Liberibacter asiaticus' (high, $\mathrm{Ct}<16.0$; medium $16.1<\mathrm{Ct}<26.0$ and low $26.1>\mathrm{Ct}$ ). Photograph was taken in 12 months after graft inoculation. Typical HLB symptom of leaf curl and corky veins on grapefruit rootstock and blotchy mottles on leaves of lemon scion were apparent.

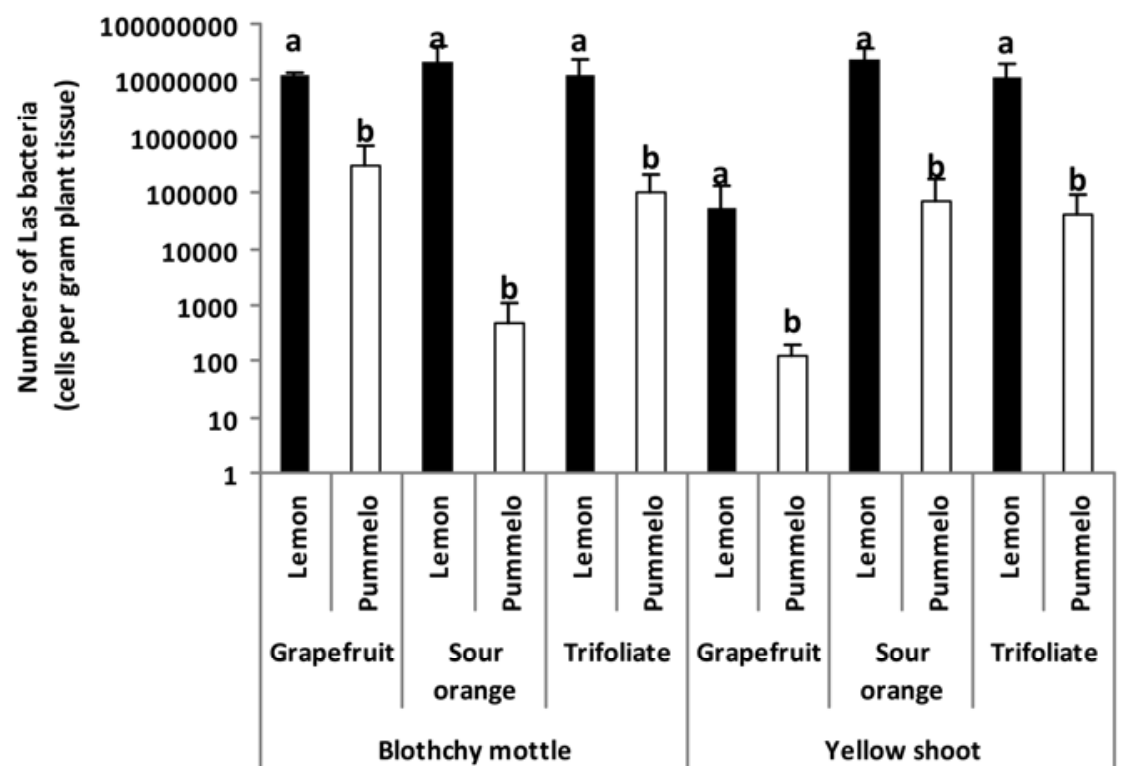

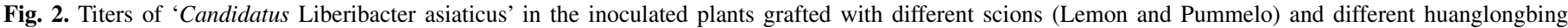

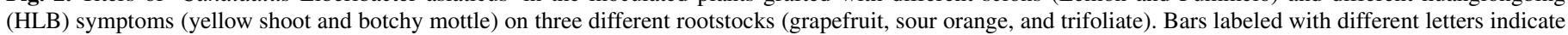
a significant difference between Lemon and Pummelo at a 95\% significance level $(P \leq 0.05)$. 
as described previously $(23,47)$. Data were analyzed by a generalized linear mixed model using the SAS procedure GLIMMIX. The whole plot and subplot factors were treated as fixed effects and replication and its interaction with the whole plot factor as random effects. Differences among treatment levels were determined with the LINES option of the LSMEANS statement.

Selection of inoculum source for graft-based Las transmission. DNA was extracted using Qiagen's DNeasy Plant Mini Kit (Qiagen, Valencia, CA) from the leaves attached to the budsticks. The inoculum titers of HLB-affected lemon budsticks were determined by qPCR as described by Li et al. (23). Grafted scions were divided into four categories: (i) severely HLB-affected scions with the $\mathrm{Ct}$ values $<16.0$, (ii) intermediately HLB-affected scions with $\mathrm{Ct}$ values of 16.1 to 26.0 , (iii) low HLB-affected scions with $\mathrm{Ct}$ values of 26.1 to 35.9 , and (iv) no symptoms with
$\mathrm{Ct}$ values $\geq 36.0$. These budsticks were then grafted onto Las-free grapefruit ('Duncan') and tested for transmission efficiency by qPCR (23).

Screening chemotherapy compounds against Las bacterium. Five compounds or mixtures were evaluated for their potential to eliminate or suppress Las bacterium in greenhouse trials: the antibiotic mixture of penicillin $\mathrm{G}$ potassium at a concentration of $1.0 \mathrm{~g} / \mathrm{liter}$ and streptomycin at a concentration of $100 \mathrm{mg} / \mathrm{liter}$ (PS) (Sigma-Aldrich, St. Louis), a $200 \mu \mathrm{l} /$ liter of $20 \%$ solution of the biocide agent 2,2-dibromo-3-nitrilopropionamide (DBNPA, Dow Chemical, Midland, MI), the antibiotic kasugamycin (Ksg, Sigma-Aldrich) at a concentration of $1.0 \mathrm{~g} /$ liter, oxytetracycline (Oxy, Sigma-Aldrich) at a concentration of $1.0 \mathrm{~g} / \mathrm{liter}$, and metronidazole (Met, Sigma-Aldrich) at a concentration of $100 \mathrm{mg} / \mathrm{liter}$.

Tap water was used as a control (CK). The 10 to $12 \mathrm{~cm}$ twigs with four of five leaves of severely HLB-affected lemon from

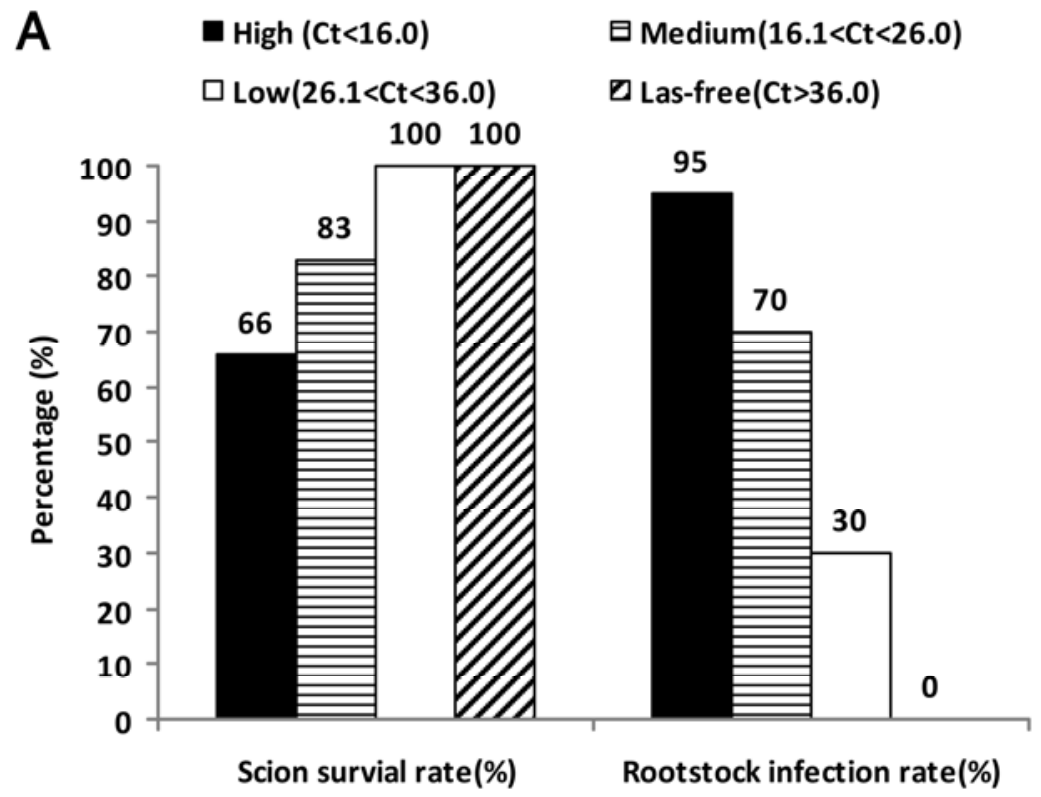

B
- High (Ct<16.0)
日 Medium $(16.1<\mathrm{Ct}<26.0)$
$\square \operatorname{Low}(26.1<\mathrm{Ct}<36.0)$
Z Las-free(Ct>36.0)

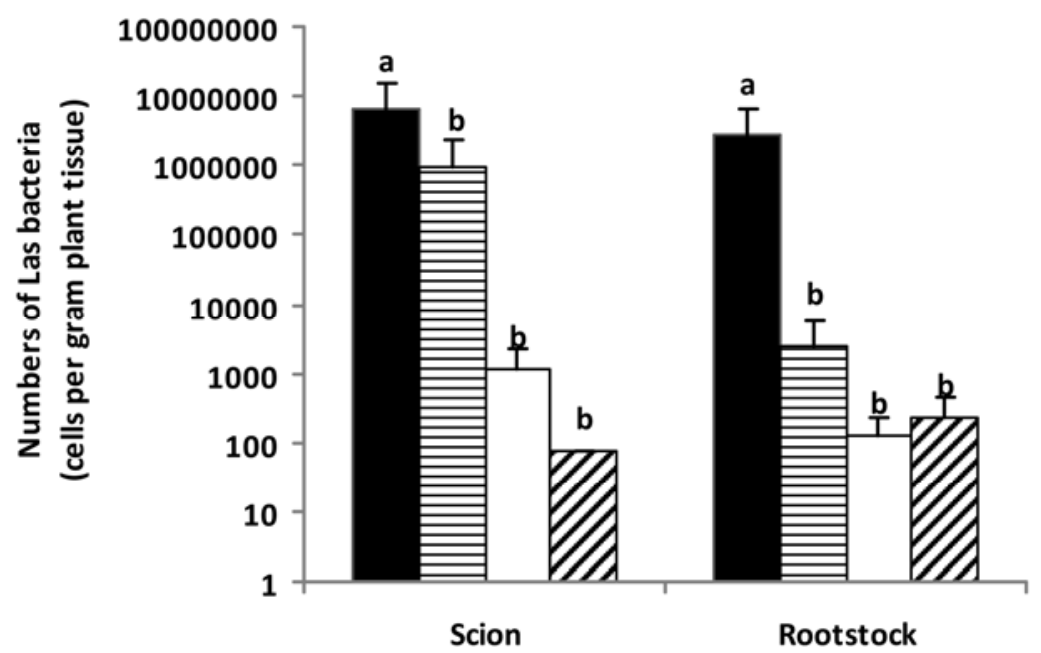

Fig. 3. A, Transmission efficiency of 'Candidatus Liberibacter asiaticus' (Las) bacterium along with scion survival rate (\%) and rootstock infection rate (\%) and B, the number of Las bacteria in the inoculated plants when grafted using different Las titers of huanglongbing-affected lemon scions on 2-year-old healthy Las-free grapefruit rootstock. Bars labeled with different letters indicate a significant difference among different inoculum sources at a $95 \%$ significance level $(P \leq 0.05)$. No significant differences were found between scions and rootstocks in the inoculated plants $(P=0.277)$. 
USHRL (U.S. Horticultural Lab) farm at Fort Pierce, Florida were individually soaked in the above solutions overnight in a fume hood under ventilation and lighting. The 3 to $4 \mathrm{~cm}$ budsticks (scions) were cut off and then grafted onto 2-year-old healthy grapefruit rootstocks. The titers of Las bacteria were determined by $\mathrm{qPCR}$ as described previously $(23,47)$. Each experiment was replicated with 45 scions.

Rescuing severely HLB-affected citrus germplasms. Budsticks were taken from the severely HLB-affected citrus germplasms (Campbell Valencia, Kona, Cleopatra Mandarin, and Sugiyama) planted in the field at the USDA-ARS-USHRL farm in Fort Pierce and then soaked in a PS solution (the antibiotic mixture of penicillin $\mathrm{G}$ potassium at a concentration of $1.0 \mathrm{~g} / \mathrm{liter}$ and streptomycin at a concentration of $100 \mathrm{mg} / \mathrm{liter}$ ) overnight in the fume hood under ventilation and lighting. Budsticks from
HLB-affected lemon soaked in water were used as controls (CK). The budsticks were grafted onto 2-year-old healthy trifoliate rootstocks as above. To keep the scions growing, all branches from the rootstock were removed. Five leaf samples were taken from the scions at 4 months after inoculation, then at 2-month intervals for 1 year. DNA was isolated for qPCR analysis as described previously $(23,47)$.

\section{RESULTS}

Response of citrus scions and rootstocks to Las bacteria. HLB symptoms normally appeared on the new shoots 4 to 5 months after inoculation. Typical blotchy mottle on leaves was only observed on the lemon, while leaf curl and corky veins appeared on the grapefruit rootstock. Less prominent blotchy

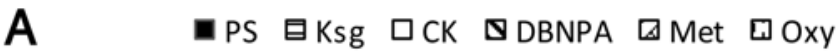
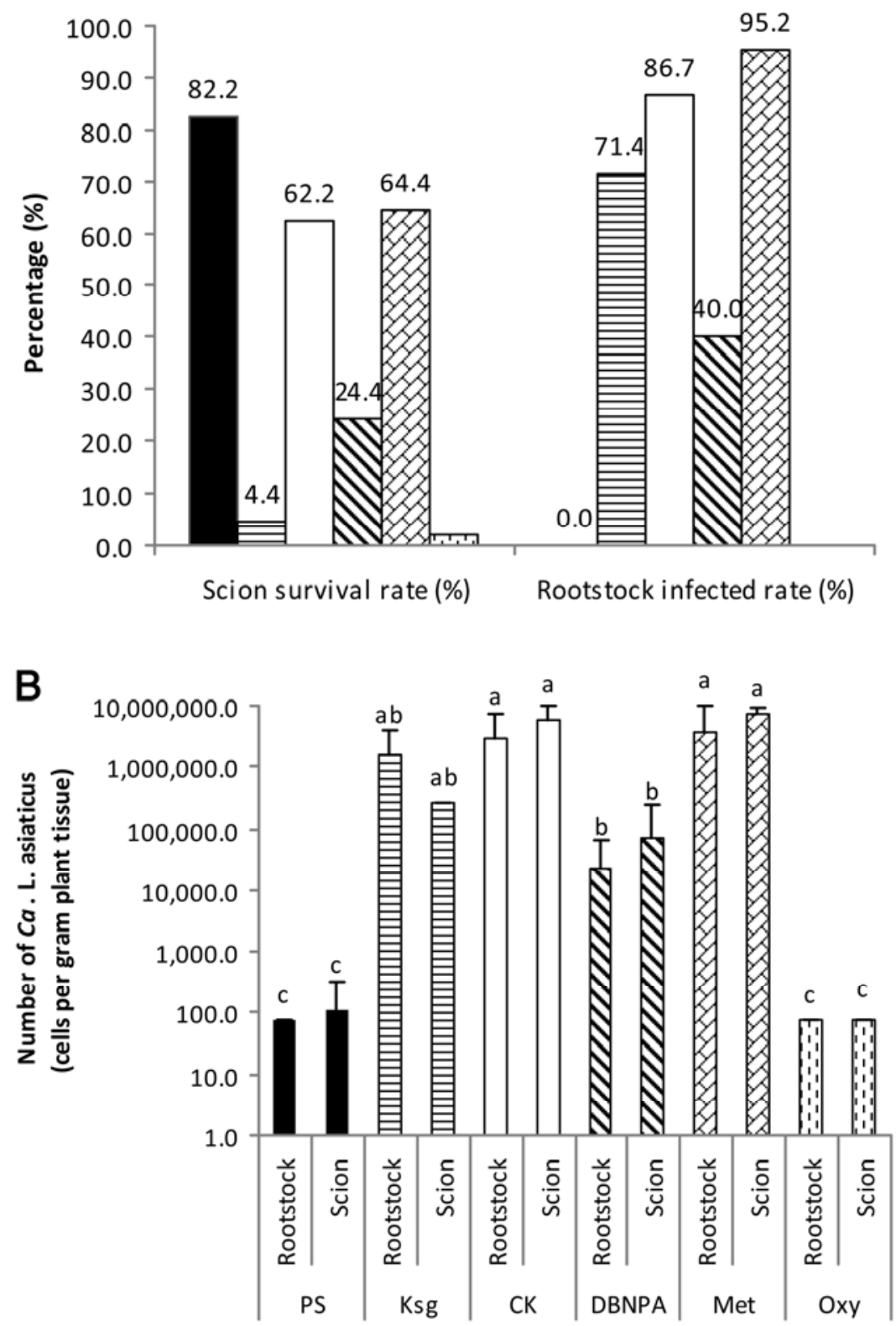

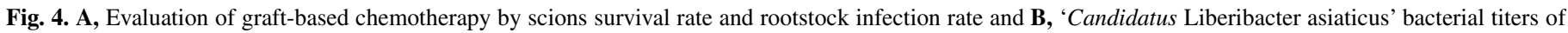

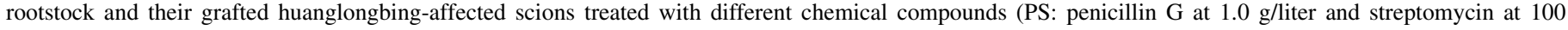

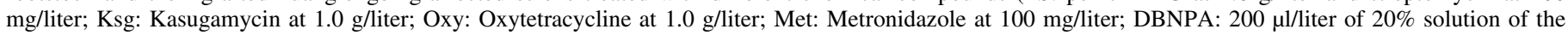

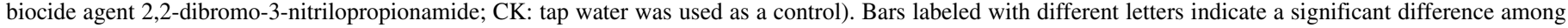

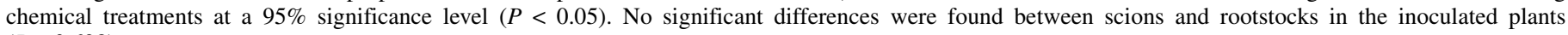
$(P=0.698)$. 
mottle also appeared on trifoliate orange leaves. Late symptoms in all Las-positive plants included defoliation with yellow and curved leaves at the apex (Fig. 1). The survival rate of the infected grafts varied from $54.5 \%$ for pummelo to $63.0 \%$ for lemon with an average of $58.7 \%$. Trifoliate orange as a rootstock had the highest scion survival rate ranging from 64.3 to $78.6 \%$ with an average of $73.2 \%$ when compared with the grapefruit or sour orange as rootstock (about $50 \%$ on average). When correlated with types of HLB symptoms, the Las bacterium was transmitted at a higher rate in scions with blotchy mottle $(48.4 \%)$ than those with yellow shoot $(25.1 \%)$. There was significant variation in Las bacterial transmission between lemon $(58.9 \pm 29.9 \%)$ and pummelo $(14.6 \pm 12.9 \%)$ as inoculum sources $(P=0.022)$, but no significant differences among the species of rootstocks $(P=$ 0.524 ) (Table 1).

The highest Las bacterial titers were observed in plants receiving the grafted inocula of lemon with blotchy mottle symptoms. This inoculum type had a 23-fold higher Las titer than the pummelo inoculum (Fig. 2). No significant differences in Las bacterial titers were found among the tested rootstocks (sour orange, grapefruit, and trifoliate) $(P=0.119)$ or between the types of HLB symptoms (yellow shoot versus blotchy mottle) $(P=0.292)$.

Successful transmission occurred only with a relatively high titer of Las bacterium in the scion inoculums, the higher the Las bacterial titers, the higher its transmission efficiency. Transmission efficiencies were over $70.0 \%$ when the Las bacterial titers in the scions were greater than $1.96 \times 10^{5}$ cells per gram of plant tissue (Ct value lower than 26.0), resulting in higher titers of Las bacteria in the inoculated citrus. This was also evident in those grafted with a severely HLB-affected scion that had a Las bacterial titer of $1.44 \times 10^{8}$ cells per gram of plant tissue $(\mathrm{Ct}$ value lower than 16.0) (Fig. 3). All scions survived and grew when the Las bacterial titers in the grafted scions were lower than 1,000 cells per gram of plant tissue (Ct value more than 36.0) (Fig. 3).

Screening chemical compounds for eliminating or suppressing Las bacterium. More than $80 \%$ of the PS-treated scions survived and grew better than those receiving other treatments. No Las bacteria were detected in the PS-treated scions, indicating that PS was effective in eliminating the Las bacterium in the HLB-affected scions. Similar to the water control, the HLBaffected scions treated with Met yielded more than $60.0 \%$ survival and new growth. However, more than $85.0 \%$ of the grafted plants tested positive for Las bacteria, and the inoculated plants kept the highest Las bacterial titers of all treatments. Antibiotics Ksg and Oxy each at concentrations of $1.0 \mathrm{~g} /$ liter were observed to be phytotoxic to the scions with survival rates of less than $5.0 \%$. In the Ksg treatment, more than $70.0 \%$ of the grafted plants tested positive for Las bacteria with the average titer of $9.44 \times 10^{5}$ cells per gram of plant tissue. No grafted plants tested positive for Las bacteria in the Oxy treatment. As in a previous report, DBNPA could partly suppress the Las bacterium $(46,47)$. Forty percent of grafted plants tested positive for Las bacterium with an average titer of $4.7 \times 10^{4}$ cells per gram of plant tissue in the DBNPA-treatment (Fig. 4).

Recovery of severely HLB-affected germplasms. The effective compound PS was used to treat budsticks of four severely HLB-affected citrus germplasms (Campbell Valencia, Kona, Cleopatra Mandarin, and Sugiyama) from the USHRL farm. All PS-treated, grafted citrus tested negative for Las bacterium by qPCR 4 months to 1 year post-grafting (Fig. 5), indicating that severely HLB-affected citrus germplasms and valuable breeding materials can be rescued (Fig. 6).

\section{DISCUSSION}

HLB has been a major impediment to citrus production for over a century in Asia. The recent introduction of the disease to Brazil and the United States, two major producers of citrus, makes its impact far more significant worldwide $(3,19)$. The disease is difficult to control due to the lack of HLB-resistant citrus cultivars and effective control methods (6,20). In this study, an effective graft-based chemotherapy method was developed to quickly screen and evaluate chemical compounds against the HLB bacteria. The ability to rescue severely HLB-affected citrus germplasms or breeding materials allows the production of Las-free nursery stocks for the citrus industry.

Pathogen survival and transmission rates are vital for the efficient evaluation of chemical compounds against the HLB bacteria. In the HLB pathosystem, pathogen inoculation and transmission studies often use the infected plants as a direct inoculum source. When compared with insect $(21)$ or dodder $(16,17)$ transmission, a graft-based method had a higher efficiency of pathogen transmission. However, many factors such as age and amount of infected tissue, titer of bacterial pathogen, and scion-rootstock combination can significantly affect Las bacterial transmission rate (24). It was reported that transmission efficiencies ranged from 25.0 to $65.2 \%$ for $\approx 4$-cm-long budsticks collected from symptomatic branches, but 10.0 to $17.1 \%$ for $2 \mathrm{~cm}$ long budsticks with a single bud (24). In this study, transmission efficiency ranging from 64.3 to $100 \%$ was observed using the lemon with

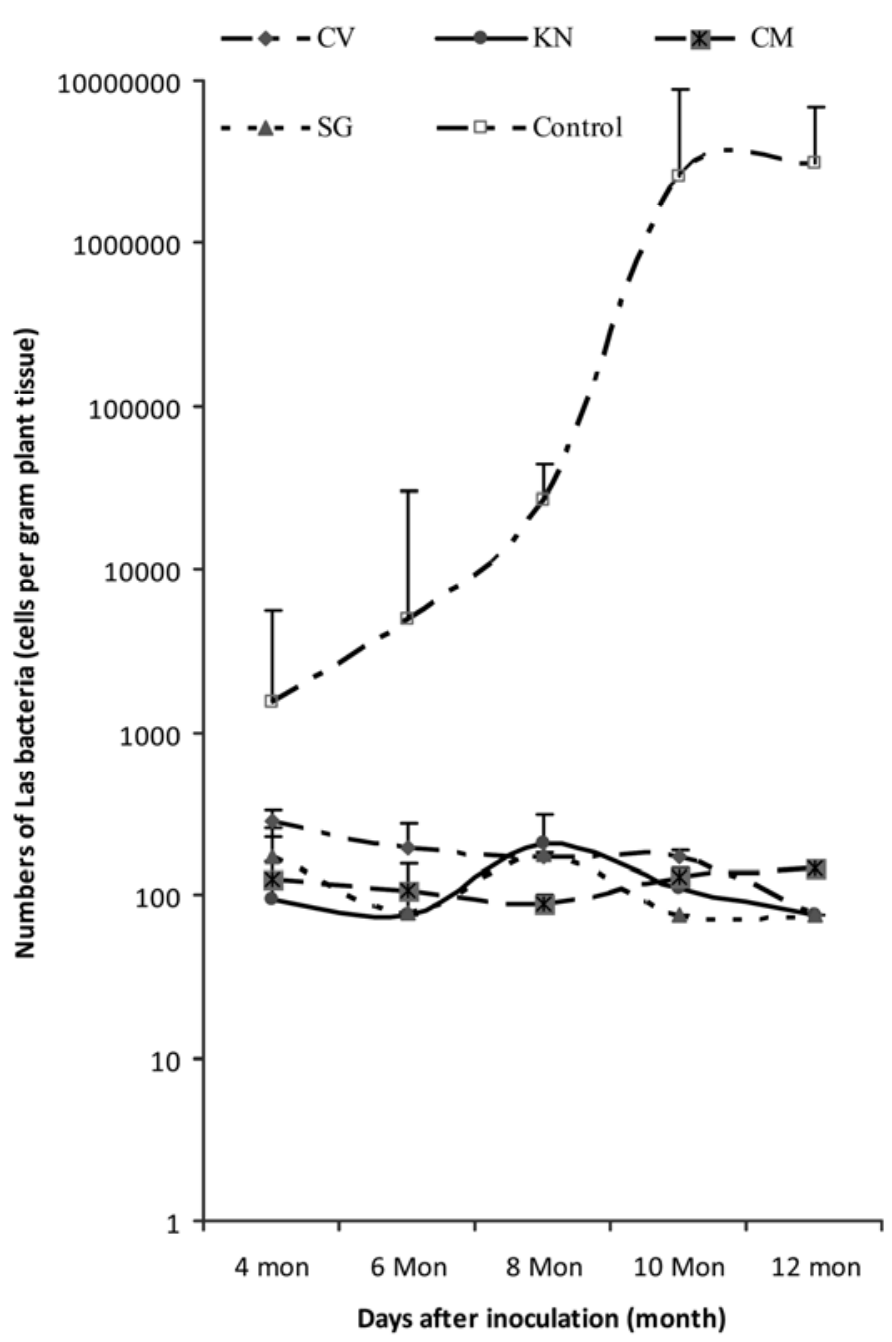

Fig. 5. Number of 'Candidatus Liberibacter asiaticus' bacteria in the rescued citrus plants from four severely huanglongbing (HLB)-affected citrus germplasms (CV, Campbell Valencia; KN, Kona; CM, Cleopatra Mandarin; and SG, Sugiyama) whose budsticks were treated with the PS solution and grafted on to healthy rootstock (penicillin at $1.0 \mathrm{~g} /$ liter and streptomycin at $100 \mathrm{mg} / \mathrm{liter}$ ). Control was the budsticks from HLB-affected lemon soaked in water. 
blotchy mottle symptoms as the inoculum, followed by lemon with yellow shoot symptoms (ranging from 11.1 to $62.5 \%$ ), and by pummelo with blotchy mottle or yellow shoot (ranging from 0.0 to $33.3 \%$ ). The Las bacterial transmission was significantly affected by Las bacterial titers of HLB-affected scion inoculum (budsticks). The higher the Las bacterial titer in the inoculum, the higher the transmission efficiency, but the lower the scion survival rate.

Scion survival is one of the most important factors that should be considered in graft transmission, and it can be affected by the compatibility, intimate contact and physiological stage (vigor, phytohormones, nutrients and other physiological factors) of the rootstock and scion, as well as the grafting environment $(26,32)$. Our results indicated that overall survival percentage of scions varied from $30.0 \%$ in pummelo to $83.3 \%$ in lemon with an average of $58.7 \%$. The lower the titer of Las bacterium, the higher the survival rate of the scion. Survival rates also varied with the rootstocks. Trifoliate, a widely used commercial rootstock (11, $39)$, had the highest survival rate $(>70.0 \%)$ compared with the grapefruit $(52.6 \%)$ and sour orange $(50.4 \%)$. Compared with the previous screening system using Las-infected periwinkle cuttings (46), which had a survival rate of $60.6 \%$, the graft-based method using Las-infected citrus scions had a higher survival rate of infected lemon scions (83.3\%). Although the citrus graft-based method requires a longer period of time for evaluation than the periwinkle cutting system, it is a direct method for screening molecules for the control of HLB while assessing their phytotoxicity to citrus.

The diffusion of molecules inside plants depends on their size and concentrations, solubility in water or organic solvents, permeability of the membrane, and temperature $(4,8,9,40)$. Water and minerals absorbed by roots are transported by xylem and the organic material synthesized in the leaves is transported to other parts of the plant through phloem (25). When applied to the stem or leaves of citrus, Systox (a type of insecticide) was translocated both up and down in the phloem, then diffused into the xylem and moved past girdles in the stem. The rate of movement in the phloem was from 2.5 to $10 \mathrm{~cm}$ per hour (45). Based on these conditions, the antibiotics, Oxy, the mixtures of penicillin and streptomycin (PS), Met, and Ksg, were evaluated for their activity against Las bacterium and their phytotoxicity by soaking the HLB-affected budsticks in these compounds and then grafting them onto trifoliate rootstocks. The screened results were similar to previous reports $(46,47)$. The results presented here demonstrated that Oxy and PS were effective in eliminating the Las bacterium in the graft-inoculated plants, but Oxy at the concen-
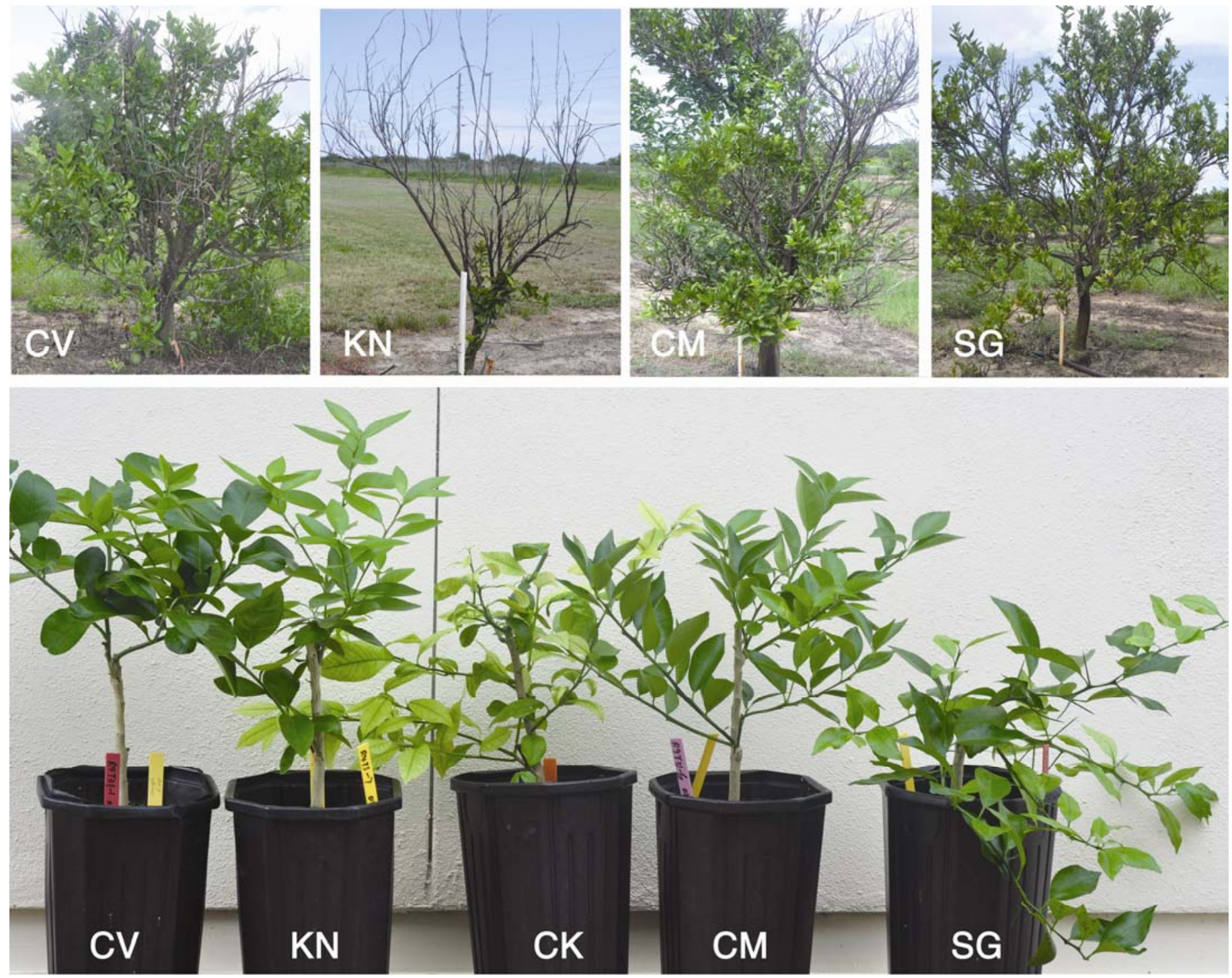

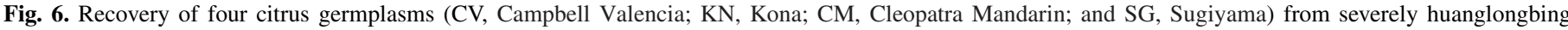

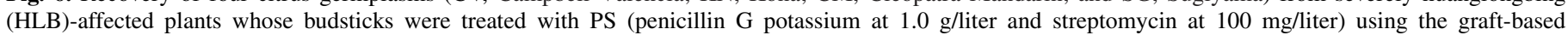
chemotherapy method. Control (CK) was the budsticks from HLB-affected lemon soaked in water. 
tration of $1.0 \mathrm{~g} /$ liter had severe phytotoxicity that resulted in only $2.2 \%$ of scion survival. Currently, tetracycline has been the only antibiotic to be approved for use through injection into the trunks of palms and elm trees to control the lethal phytoplasma yellow diseases $(28,29)$. Met, a nitroimidazole antibiotic (14), at the concentration of $100 \mathrm{mg} /$ liter did not have any effects on suppressing or eliminating the Las bacterium in the HLB-affected budsticks. More than $95.0 \%$ of grafted plants were infected by Las bacterium. Ksg, an aminoglycoside antibiotic, inhibits proliferation of bacterium by interference with protein synthesis $(1,43)$. The results showed that Ksg applied alone was not effective in eliminating or suppressing Las and had a phytotoxicity that resulted in less than $5.0 \%$ of scion survival when treated at a concentration of $1.0 \mathrm{~g} /$ liter. DBNPA, a fast-acting and broadspectrum biocide that has been widely used in industrial water systems, was also evaluated (5). Similar to the previous report from Las-infected periwinkle cuttings, DBNPA could partly suppress the Las bacterium (46). More than $40.0 \%$ of the grafted plants tested positive for Las bacterium with 46,656 cells per gram of plant tissues. These results indicate this graft-based method is a relatively quick and cost-effective way for screening effective molecules for the control of citrus HLB, and PS is the most effective chemical compounds tested. This method is being used to screen more than 80 compounds selected from the worldwide challenge sponsored by the Florida Citrus Research and Development Foundation, which may result in additional compounds useful for the control of citrus HLB.

HLB is one of the graft transmissible diseases that can occur through the use of infected budsticks (24). Hence, the establishment of disease-free foundation plants is imperative in providing certified budsticks to growers $(31,34,36,37,42)$. The studies here suggested that the Las bacterium in the HLB-affected budsticks can be successfully eliminated through treatment with effective compounds, such as PS. Obtaining pathogen-free citrus plants is one of the most important steps in the "Citrus Variety Improvement Program” in Spain (35), Turkey (18), Brazil (38), and China $(13,42)$. The production of clean material is essential for the conservation and use of citrus genetic resources (10). Our graftbased chemotherapy method will not only be useful for propagating disease-free citrus nursery stocks, but also may be applied for screening effective chemical compounds for similar diseases.

\section{ACKNOWLEDGMENTS}

This work was supported by the Florida Citrus Advanced Technology Program award 161 and 162. We thank C. Latza and G. Brock for their excellent technical assistance in the research.

\section{LITERATURE CITED}

1. Adaskaveg, J. E., Förster, H., and Wade, M. L. 2011. Effectiveness of kasugamycin against Erwinia amylovora and its potential use for managing fire blight of pear. Plant Dis. 95:448-454.

2. Bassanezi, R. B., Montesino, L. H., Gasparoto, M. C. G., Bergamin Filho, A., and Amorim, L. 2011. Yield loss caused by huanglongbing in different sweet orange cultivars in São Paulo, Brazil. Eur. J. Plant Pathol. 130:577-586

3. Batool, A., Iftikhar, Y., Mughal, S. M., Khan, M. M., Jaskani, M. J., Abbas, M., and Khan, I. A. 2007. Citrus greening disease-A major cause of citrus decline in the world. A Review. Hort. Sci. (Prague) 4:159-166.

4. Baur, P., Buchholz, A., and Schönherr, J. 1997. Diffusion in plant cuticles as affected by temperature and size of organic solutes: Similarity and diversity among species. Plant Cell Environ. 20:982-994.

5. Blanchard, F. A., Gonsior, S. J., and Hopkins, D. L. 1987. 2,2-Dibromo3-nitrilopropionamide (DBNPA) chemical degradation in natural watersexperimental evaluation and modeling of competitive pathways. Water Res. 21:801-807.

6. Bové, J. M. 2006. Huanglongbing: A destructive, newly-emerging, century-old disease of citrus. J. Plant Pathol. 88:7-37.

7. Bové, J. M., and Ayres, A. J. 2007. Etiology of three recent diseases of citrus in São Paulo State: Sudden death, variegated chlorosis and huang- longbing. IUBMB Life 59:346-354.

8. Buchholz, A., Baur, P., and Schönherr, J. 1998. Differences among plant species in cuticular permeabilities and solute mobilities are not caused by differential selectivity. Planta 206:322-328.

9. Buchholz, A., and Schönherr, J. 2000. Thermodynamic analysis of diffusion of non-electrolytes across plant cuticles in the presence and absence of the plasticiser tributyl phosphate. Planta 212:103-111.

10. Carimi, F., and Pasquale, F. D. 2001. Conservation strategies of citrus germplasm: In vitro and in vivo. Options Méditer. Série B 33:67-72.

11. Castle, W. S., Baldwin, J. C., and Muraro, R. P. 2010. Rootstocks and the performance and economic returns of 'Hamlin' sweet orange trees. Hortscience 45:875-881.

12. Coletta-Filho, H. D., Carlos, E. F., Alves, K. C. S., Pereira, M. A. R., Boscariol-Camargo, R. L., de Souza, A. A., and Machado, M. A. 2010. In planta multiplication and graft transmission of 'Candidatus Liberibacter asiaticus' revealed by real-time PCR. Eur. J. Plant Pathol. 126:53-60.

13. Deng, X. X. 2008. Citrus breeding and genetic improvement programme in China. Pages 17-23 in: Proc. XXVII IHC-S16 Citrus and Other Trop. \& Subtrop. Fruit Crops. Acta Hort. 773, ISHS, Belgium.

14. Edwards, D. I. 1980. Mechanisms of selective toxicity of metronidazole and other nitroimidazole drugs. Br. J. Vener Dis. 56:285-290.

15. Folimonova, S. Y., Robertson, C. J., Garnsey, S. M., Gowda, S., and Dawson, W. O. 2009. Examination of the responses of different genotypes of citrus to Huanglongbing (citrus greening) under different conditions. Phytopathology 99:1346-1354.

16. Garnier, M., and Bové, J. M. 1983. Transmission of the organism associated with citrus greening disease from sweet orange to periwinkle by dodder. Phytopathology 73:1358-1363.

17. Garnier, M., Danel, N., and Bové, J. M. 1984. Transmission of citrus greening disease from sweet orange to periwinkle (Vinca-Rosea) by dodder (Cuscuta campestris) and proof of the bacterial nature of the organism. Yale J. Biol. Med. 57:904-904.

18. Goral, T., Tagdemir, H. Ali, Davarci, Mermer, T. S., Kelten, G. M., Tagdemir, T., Giineg, S., and Gogmen, M. 2000. The citrus variety improvement program in Turkey. Pages 401-405 in: Proc. 12th Conf. Int. Org. Citrus Virol. P. Moreno, J. V. da Graça, and L. W. Timmer, eds. IOCV, University of California, Riverside.

19. Gottwald, T. R. 2010. Current epidemiological understanding of citrus Huanglongbing. Annu. Rev. Phytopathol. 48:119-139.

20. Gottwald, T. R., da Graca, J. V., and Bassanezi, R. B. 2007. Citrus Huanglongbing: The pathogen and its impact. Online. Plant Health Progress. doi: 10.1094/PHP-2007-0906-01.

21. Halbert, S. E., and Manjunath, K. L. 2004. Asian citrus psyllids (Sternorrhyncha: Psyllidae) and greening disease of citrus: A literature review and assessment of risk in Florida. Fla. Entomol. 87:330-353.

22. Jagoueix, S., Bové, J. M., and Garnier, M. 1994. The phloem-limited bacterium of greening disease is a member of the $\alpha$ subdivision of the proteobacteria. Int. J. Syst. Bacteriol. 44:379-386.

23. Li, W. B., Hartung, J. S., and Levy, L. 2008. Optimized quantification of unculturable 'Candidatus Liberibacter spp.' in host plants using real-time PCR. Plant Dis. 92:854-861.

24. Lopes, S. A., and Frare, G. F. 2008. Graft transmission and cultivar reaction of citrus to 'Candidatus Liberibacter americanus'. Plant Dis. 92:21-24.

25. Lough, T. J., and Lucas, W. J. 2006. Integrative plant biology: Role of phloem long-distance macromolecular trafficking. Annu. Rev. Plant Biol. 57:203-232.

26. Maiti, R. G., Singh, S. M., and Singh, I. J. 1959. Effect of type of scion buds and plant regulators on the success of bud grafting in grapefruit. Indian J. Hortic. 16:149-152.

27. Manjunath, K. L., Halbert, S. E., Ramadugu, C., Webb, S., and Lee, R. F. 2008. Detection of Candidatus Liberibacter asiaticus in Diaphorina citri and its importance in the management of citrus huanglongbing in Florida. Phytopathology 98:387-396.

28. McCoy, R. E. 1982. Use of tetracycline antibiotics to control yellows diseases. Plant Dis. 66:539-542.

29. McManus, P. S., Stockwell, V. O., Sundin, G. W., and Jones, A. L. 2002. Antibiotic use in plant agriculture. Annu. Rev. Phytopathol. 40:443-465.

30. Miyakawa, T. 1980. Experimentally-induced symptoms and host range of citrus Likubin (green disease). Ann. Phytopathol. Soc. Japan 46:224-230.

31. Mukhopadhyay, S., Raj, J., Sharma, B. C., Gurung, A., Sengupta, R. K., and Nath, P. S. 1997. Micropropagation of darjeeling orange (Citrus reticulata Blanco) by shoot-tip grafting. J. Hortic. Sci. 72:493-499.

32. Murashige, T., Bitters, W. P., Rangan, E. M., Nauer, E. M., Roistacher, C. N., and Holliday, P. B. 1972. A technique of shoot apex grafting and its utilization towards recovering virus-free citrus clones. HortScience 7:118-119.

33. Nariani, T. K., Raychaudhuri, S. P., and Viswanath, S. M. 1973. Tolerance to greening disease in certain citrus species. Curr. Sci. Bangalore 42:513-514. 
34. Navarro, L. 1988. Application on shoot-tip grafting in vitro to woody species. Acta Hort. 227:43-55.

35. Navarro, L., Pina, J. A., Juárez, J., Ballester-Olmos, J. F., Arregui, J. M., Ortega, C., Navarro, A., Duran-Vila, N., Guerri, J., Moreno, P., Cambra, M., Medina, A., and Zaragoza, S. 2002. The citrus variety improvement program in Spain in the period 1975-2001. Pages 306-316 in: Proc. 15th Conf. Int. Org. Citrus Virol. N. Duran-Vila, R. G. Milne, and J. V. da Graça, eds. IOCV, University of California, Riverside.

36. Navarro, L., Roistacher, C. N., and Murashige, T. 1975. Improvement of shoot-tip grafting in vitro for virus-free citrus. J. Am. Soc. Hort. Sci. 100:471-479.

37. Naz, A. A., Jaskani, M. J., Abbas, H., and Qasim, M. 2007. In vitro studies on micrografting technique in two cultivars of citrus to produce virus free plants. Pak. J. Bot. 39:1773-1778

38. Santos Filho, H. P., Passos, O. S., da Cunha Sobrinho, A. P., Barbosa, C. de J., and Nickel, O. 2000. The citrus variety improvement program in northeastern Brazil after 15 Years. Pages 403-404 in: Proc. 14th Conf. Int. Org. Citrus Virol. P. Moreno, J. V. da Graça, and L. W. Timmer, eds. IOCV, University of California, Riverside.

39. Schneider, H., and Pehrson, J. E., Jr. 1985. Decline of navel orange trees with trifoliate orange rootstocks. Calif. Agric. 9:13-16.

40. Schreiber, L. 2005. Polar paths of diffusion across plant cuticles: New evidence for an old hypothesis. Ann. Bot. 95:1069-1073.

41. Shokrollah, H., Abdullah, T. L., Sijam, K., and Abdullah, S. N. K. 2011.
Potential use of selected citrus rootstocks and interstocks against HLB disease in Malaysia. Crop Prot. 30:521-525.

42. Su, H. J. 2008. Production and Cultivation of Virus-free Citrus Saplings for Citrus Rehabilitation in Taiwan. Asia-Pacific Consortium on Agricultural Biotechnology, New Delhi and Asia-Pacific Association of Agricultural Research Institutions, Bangkok.

43. Tanaka, N., Yamaguchi, H., and Umezawa, H. 1966. Mechanism of kasugamycin action on polypeptide synthesis. J. Biochem. 60:429-434.

44. Teixeira, D. C., Ayres, A. J., Kitajima, E. W., Tanaka, F. A. O., Danet, J. L., Jagoueix-Eveillard, S., Saillard, C., and Bové, J. M. 2005. First report of a Huanglongbing-like disease of citrus in São Paulo State, Brazil, and association of a new liberibacter species, "Candidatus Liberibacter americanus", with the disease. Plant Dis. 89:107.

45. Wedding, R. T. 1953. Plant physiological aspects of the use of systemic insecticides. J. Agric. Food Chem. 1:832-834.

46. Zhang, M. Q., Duan, Y. P., Zhou, L. J., Turechek, W. W., Stover, E., and Powell, C. A. 2010. Screening molecules for control of citrus huanglongbing using an optimized regeneration system for 'Candidatus Liberibacter asiaticus'-infected periwinkle (Catharanthus roseus) cuttings. Phytopathology 100:239-245.

47. Zhang, M. Q., Powell, C. A., Zhou, L. J., He, Z. L., Stover, E., and Duan, Y. P. 2011. Chemical compounds effective against the citrus Huanglongbing bacterium 'Candidatus Liberibacter asiaticus' in planta. Phytopathology 101:1097-1103. 